\title{
Quantitative extraction of living meiofauna from marine and brackish muddy sediments
}

\author{
Werner Armonies \& Monika Hellwig
}

II. Zoologisches Institut und Zoologisches Museum - Zoomorphologie und Ókologie, Georg-August-Universität Göttingen, D-3400 Göttingen, Federal Republic of Germany

\begin{abstract}
A method for extracting living meiofauna from marine and brackish water mud is proposed and tested. Samples are fitted into tubes and covered with a $2 \mathrm{~cm}$ layer of clean coarse sand. Water of appropriate salinity is added until the sample is flooded and the sandy cover is just moist. Sample tubes are closed and stored in the dark. As the samples become anaerobic, the animals migrate upwards into the sandy layer. To extract them, the sandy cover is separated periodically and washed out by 10 -fold shaking and rotating in a beaker. The supernatant is decanted through small funnels, and animals are retained on a $40 \mu \mathrm{m}$ gauze. Total extraction of 1 sample takes about half an hour. This extraction procedure is compared to grain-by-grain investigation of the whole sample. Within the sites tested, Plathelminthes, Polychaeta, Oligochaeta, Copepoda, and Ostracoda were extracted quantitatively. Extraction of Nematoda and Halacarida was not always complete. In some cases, extraction even yielded significantly higher numbers of Oligochaeta and Plathelminthes than control sorting.
\end{abstract}

\section{INTRODUCTION}

Quantitative extraction is essential for ecological population studies. For marine sediments, various methods have been proposed (see Uhlig 1964, 1968, Hulings \& Gray 1971, Uhlig et al. 1973, Martens 1984, Noldt \& Wehrenberg 1984). However, in investigating Plathelminthes of marine and brackish muddy sediments, which often enclose rootage or fragments of roots, we found no method satisfying the following demands: (1) quantitative extraction; (2) extraction of undamaged living animals (needed for determination of species, e.g. taxon Plathelminthes); (3) 'short-time' extraction, which enables one to deal with higher numbers of parallel samples; and (4) 'purificatory' extraction, i.e. a procedure which delivers animals separate from other material present in the samples, such as mud, detritus, and root fragments. The method proposed in this paper is based on 'Klimaverschlechterung' (cf. Riedl 1953). With several modifications and improvements the new method yields quantitative extraction of living specimens of the taxa Plathelminthes, Polychaeta, Oligochaeta, Copepoda, and Ostracoda. In some cases, Nematoda and Halacarida were not extracted quantitatively.

(c) Inter-Research/Printed in F. R. Germany

\section{MATERIAL AND METHODS}

Sampling. In testing the efficiency of the method proposed, 2 sites were sampled. Marine samples were collected on September 10,1983 at a small Spartina townsendii marsh north of Kampen (island of Sylt, eastern part of the North Sea). About $10 \mathrm{~cm}$ above mean high tide level, 20 samples of $2 \mathrm{~cm}^{2}$ surface area each were taken from a $20 \times 20 \mathrm{~cm}$ plot at random. The uppermost 1 to $1.5 \mathrm{~cm}$ of sediment were brownish, deeper layers black, indicating oxic and anaerobic conditions, respectively. The samples extended down to the black stratum, including the first $5 \mathrm{~mm}$ of the anaerobic sediment. Median grain size was $55 \mu \mathrm{m}$, $25 \%$ of sediment was finer than $21 \mu \mathrm{m}$, another $25 \%$ coarser than $106 \mu \mathrm{m}$. Organic matter content was about $14 \%$ of dry weight (combustion method: weight loss after $6 \mathrm{~h}$ at $650^{\circ} \mathrm{C}$ ).

Brackish water samples were collected on September 2, 1983 in a salt marsh in the northernmost part of the island of Sylt (upper region of Puccinellion maritimae). About $60 \mathrm{~cm}$ above mean high tide level, 20 samples of $5 \mathrm{~cm}^{2}$ surface area each were taken from a $20 \times 20 \mathrm{~cm}$ plot at random. Salinity was $12 \%$. The samples extended downward to 2 to $3 \mathrm{~cm}$, including 
the upper $5 \mathrm{~mm}$ of anaerobic sediment. Median grain size was $47 \mu \mathrm{m}, 25 \%$ of sediment was finer than $23 \mu \mathrm{m}$, another $25 \%$ coarser than $113 \mu \mathrm{m}$. Organic matter content was $28.3 \%$ of dried sediment. Thus, the sediment of both sites may be described as sandy mud.

Extraction. The 20 samples of each site were divided into 2 groups at random. Control samples were washed in a beaker with filtered water. At all times Spartina marsh samples were treated with sea water, while for salt marsh samples brackish water containing $12 \%$ salt was used. The beaker was shaken and decanted into a set of Petri dishes until neither water nor sediment remained. The roots of salt marsh plants were picked to pieces. Each sample in the control series required 80 to 100 Petri dishes.

Extraction samples remained in transport tubes, with the anaerobic part of the sample to the bottom. When returned to the laboratory, the tube was filled with fractionated clean sand up to $2 \mathrm{~cm}$ above the sample surface. We used dune sand that had been washed with fresh water, dried, and fractionated by sieving. Only the portion of grain sizes 500 to $1000 \mu \mathrm{m}$ was used. Filtered water of the appropriate salinity was added until the water level within the tube reached the surface of the sample and the sand above was just moistened. The tubes were closed and stored in the dark.

During the following days, samples gradually became anaerobic. Animals inside the sample are expected to follow the oxygen gradient and to creep upwards into the sand cover. Periodical separation of the sand cover is the second step of extraction. In regular investigations this was done after 1,2 and $4 \mathrm{~d}$ of storage. In this study, shorter intervals were chosen to demonstrate the course of extraction.

The sand cover is separated from the underlying dark sample by a gentle stream of water from a squeeze-bottle and is washed into a beaker. The more clay and the less sand the sediment sampled contains, the better the added sand cover can be separated again. A higher percentage of sand will cause more fine material to be washed off from the sample, and inspection of the Petri dishes will take more time. If the sediment is held together by rootage, the amount of mud washed off is generally small. In addition, the size of tubes and samples will influence the amount of sediment separated together with the sandy cover. We obtained optimum results by using samples of 2 to $10 \mathrm{~cm}^{2}$ surface area within tubes of 3 to $4.5 \mathrm{~cm}$ in diameter. The better a sample fits into the tube, the less sediment will be washed out.

When the sandy cover has been separated, the tube is refilled with sand, moistened again, and once more stored. To the separated sand 5 to 10 times its own volume of water is added. The beaker is gently shaken, and the supernatant is decanted into a second beaker. The procedure of decantation is repeated 10 times with increasing rigorous shaking and rotating, and the supernatants are collected in the second beaker. Samples larger than $10 \mathrm{~cm}^{2}$ surface area will require more sand to be added. However with a larger quantity of sand, washing of the animals by shaking and rotating within a beaker becomes less effective. By using 10 to $20 \mathrm{~cm}^{3}$ of sand in a $600 \mathrm{~cm}^{3}$ beaker we obtained best results: when shaking and rotating was repeated 5 times, more than $90 \%$ of the number of individuals separated by a 10 -fold repetition were extracted. Attachment of meiofauna to sand grains, as has been observed in sandy environments (Ax 1969, Noldt \& Wehrenberg 1984), did not occur in this mud-dwelling fauna. The height of sediment columns extracted was limited to $4 \mathrm{~cm}$ by the size of the tubes used. Larger columns were divided into subsamples. Extraction of complete larger columns was not tested.

When the sand cover was separated and washed out, the supernatant gathered in the second beaker was concentrated by sieving through a set of small funnels with gauze holders (upper diameter of the funnel: $7 \mathrm{~cm}$, diameter of gauze holders: $1.8 \mathrm{~cm}$ ). As soon as the water had run through, the gauze holder was loosened from the funnel and inverted over a Petri dish. Water was squirted through the sieve, washing the residues into the Petri dish. For extraction of freeliving Plathelminthes, a set of 3 sieves was found to give best results. A sieve covered with a gauze of $0.25 \mathrm{~mm}$ mesh size proved useful for separating sand grains washed out and bigger animals. A sieve with a $63 \mu \mathrm{m}$ gauze separated medium-size animals and most of the finer detritus particles. The third sieve $(40 \mu \mathrm{m}$ mesh size) proved sufficient to separate the smallest Plathelminthes. Neither Plathelminthes nor Copepoda or Ostracoda were found in the water which had passed the set of sieves. Occasionally, some very small Nematoda or Nauplius larvae had slipped through the meshes. From the above, it is obvious that mesh sizes always have to be adapted to the size of animals investigated.

Samples were stored at field temperatures measured at time of collection. Higher temperatures will speed up, lower temperatures will delay extraction. We always used temperatures between 5 and $20^{\circ} \mathrm{C}$, depending on outside conditions.

Sorting and examination. Petri dishes were examined under a stereomicroscope. All Plathelminthes were picked out with small pipettes, squeezed, and identified to species level using a compound microscope. Members of other major taxa were merely counted.

Statistical analysis. Within salt marshes, none of the meiofauna taxa investigated were distributed at ran- 
dom (significant differences of the variance to mean ratio from the appropriate references of a chi-squaretable, $P=0.05$; Gage \& Geekie 1973). Differences of abundance were accordingly tested using the nonparametric U-test (Wilcoxon et al., in Sachs 1984).

\section{RESULTS}

Using the method proposed, all major taxa present at sample sites - except Nematoda and Halacarida in salt marsh samples - could be extracted quantitatively (Tables $1 \& 2$ ). Most of the animals were found during the first hours of extraction (Fig. 1). Nematoda, in contrast, migrated very slowly to the sandy layer, and nematode extraction of salt marsh samples was not completed in $5 \mathrm{~d}$. In Spartina marsh, however, there was no significant difference between extraction and control sorting.

In salt marsh samples extraction yielded significantly higher numbers of Oligochaeta than control sorting. In September many juvenile oligochaetes were present. These small animals often hide inside the stalks of salt marsh plants. Therefore, in control samples the number of Oligochaeta recorded was incomplete.

The numbers of plathelminth species in extraction and control series do not differ significantly. Because of the large quantity of sediment and detritus in the control samples, very small or slowly moving organisms were difficult to detect. Thus, significantly higher numbers of 'Dalyellioida' resulted in the extraction series, because of slowly moving Vejdovskya pellucida and very small organisms of Baicalellia brevituba (Tables 3 \& 4).

Table 1. Spartina marsh samples (marine); number of specimens in extraction (ex) and control series (co). SD: standard deviation; ns: not significant

\begin{tabular}{|c|c|c|c|c|c|c|c|c|c|c|c|c|c|c|}
\hline \multirow{3}{*}{$\frac{\text { Taxon }}{\text { Plathelminthes }}$} & \multicolumn{11}{|c|}{ Data $\mathrm{n} 1, \mathrm{n} 2, ., \mathrm{n} 10$} & \multirow{2}{*}{$\frac{\text { Mean }}{19.4}$} & \multirow{2}{*}{$\frac{\mathrm{SD}}{4.4}$} & \multirow[t]{2}{*}{ U-test } \\
\hline & ex & 23 & 17 & 24 & 18 & 21 & 16 & 13 & 14 & 22 & 26 & & & \\
\hline & $\mathrm{co}$ & 16 & 24 & 20 & 21 & 14 & 19 & 15 & 15 & 17 & 11 & 17.2 & 3.8 & ns \\
\hline \multirow[t]{2}{*}{ Nematoda } & ex & 49 & 32 & 21 & 23 & 39 & 54 & 22 & 50 & 50 & 33 & 37.3 & 12.9 & \\
\hline & $\mathrm{co}$ & 110 & 70 & 45 & 40 & 32 & 30 & 40 & 120 & 35 & 31 & 55.3 & 26.3 & ns \\
\hline \multirow[t]{2}{*}{ Polychaeta } & $\mathrm{ex}$ & 6 & 0 & 1 & 1 & 2 & 2 & 3 & 1 & 1 & 0 & 1.7 & 1.8 & \\
\hline & $\mathrm{co}$ & 1 & 2 & 0 & 0 & 0 & 1 & 0 & 4 & 1 & 0 & 0.9 & 1.3 & ns \\
\hline \multirow[t]{2}{*}{ Oligochaeta } & ex & 31 & 18 & 16 & 13 & 6 & 16 & 5 & 10 & 6 & 5 & 12.6 & 8.2 & \\
\hline & $\mathrm{CO}$ & 25 & 22 & 12 & 9 & 14 & 4 & 9 & 23 & 4 & 5 & 12.7 & 8.1 & ns \\
\hline \multirow[t]{2}{*}{ Copepoda } & ex & 49 & 15 & 27 & 20 & 26 & 25 & 12 & 21 & 29 & 37 & 26.1 & 10.8 & \\
\hline & co & 34 & 52 & 11 & 15 & 24 & 28 & 20 & 23 & 19 & 28 & 25.4 & 11.5 & ns \\
\hline \multirow[t]{2}{*}{ Ostracoda } & ex & 18 & 3 & 15 & 2 & 8 & 10 & 5 & 2 & 12 & 16 & 9.1 & 6.0 & \\
\hline & co & 7 & 8 & 12 & 6 & 6 & 6 & 4 & 16 & 15 & 15 & 9.5 & 4.5 & $\mathrm{~ns}$ \\
\hline \multirow[t]{2}{*}{ Halacarida } & ex & 1 & 1 & 3 & 1 & 1 & 0 & 1 & 0 & 0 & 0 & 0.8 & 0.9 & \\
\hline & $\mathrm{Co}$ & 0 & 0 & 0 & 0 & 0 & 1 & 1 & 0 & 4 & 1 & 0.7 & 1.2 & $\mathrm{~ns}$ \\
\hline \multirow[t]{2}{*}{ Hydrobia ulvae } & ex & 18 & 7 & 23 & 7 & 13 & 14 & 7 & 7 & 14 & 12 & 12.2 & 5.4 & \\
\hline & $\mathrm{Co}$ & 11 & 13 & 14 & 7 & 14 & 21 & 6 & 17 & 18 & 5 & 12.6 & 5.4 & ns \\
\hline
\end{tabular}

Table 2. Salt marsh samples (brackish); mean number of specimens in extraction (ex) and control series (co). SD: standard deviation; ns: not significant; $\cdot p \leq 0.05 ; \cdots p \leq 0.001$

\begin{tabular}{|c|c|c|c|c|c|c|c|c|c|c|c|c|c|c|}
\hline Taxon & & & & & & a $n 1$ & $2, \ldots$ & 10 & & & & Mean & $\mathrm{SD}$ & U-test \\
\hline \multirow[t]{2}{*}{ Plathelminthes } & ex & 98 & 97 & 136 & 53 & 191 & 41 & 113 & 46 & 67 & 62 & 90.4 & 47.1 & \\
\hline & $\mathrm{co}$ & 80 & 56 & 73 & 72 & 80 & 49 & 78 & 33 & 28 & 36 & 58.5 & 20.8 & ns \\
\hline \multirow[t]{2}{*}{ Nematoda } & ex & 355 & 310 & 395 & 405 & 340 & 430 & 375 & 280 & 320 & 283 & 349.3 & 51.7 & \\
\hline & $\mathrm{CO}$ & 502 & 440 & 425 & 420 & 425 & 490 & 470 & 485 & 510 & 485 & 465.2 & 34.5 & $\cdots$ \\
\hline \multirow[t]{2}{*}{ Oligochaeta } & ex & 141 & 157 & 133 & 169 & 155 & 166 & 145 & 98 & 170 & 103 & 143.7 & 25.8 & \\
\hline & co & 38 & 31 & 26 & 55 & 58 & 48 & 88 & 63 & 54 & 49 & 51.0 & 17.4 & $\cdots$ \\
\hline \multirow[t]{2}{*}{ Copepoda } & $\mathrm{ex}$ & 31 & 52 & 47 & 35 & 49 & 41 & 42 & 32 & 33 & 33 & 39.5 & 7.8 & \\
\hline & $\mathrm{co}$ & 38 & 20 & 40 & 52 & 24 & 47 & 40 & 28 & 8 & 36 & 33.3 & 13.3 & ns \\
\hline \multirow[t]{2}{*}{ Halacarida } & ex & 6 & 8 & 16 & 8 & 3 & 3 & 2 & 7 & 5 & 5 & 6.3 & 4.0 & \\
\hline & $\mathrm{CO}$ & 10 & 14 & 17 & 22 & 11 & 5 & 5 & 15 & 10 & 12 & 12.1 & 5.2 & • \\
\hline
\end{tabular}



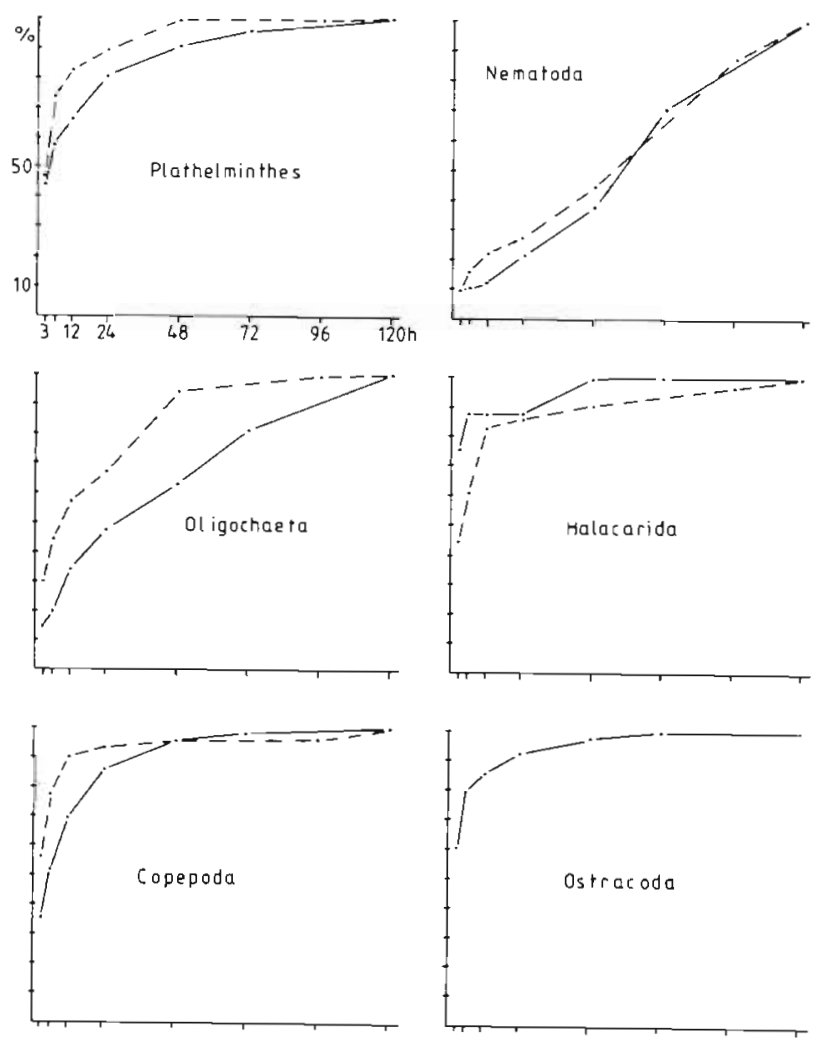

Fig. 1. Cumulative percentage extraction efficiency of frequent metazoan taxa. $100 \%$ equals number of specimens extracted within $120 \mathrm{~h}$ when extraction was stopped. Solid lines: Spartina marsh (marine); broken lines: salt marsh (brackish)
Species living near the sediment surface were extracted very quickly (e.g. Acoela), those living in deeper strata took longer to migrate into the sand cover (Kalyptorhynchia, Fig. 2).

In sediments deeper than $5 \mathrm{~mm}$ beyond the oxic/ anoxic border, no living metazoans were found with either method (see below).

\section{DISCUSSION}

Quantitative extraction of most meiofauna taxa by the procedure proposed demonstrates that vertical migration within an oxygen gradient occurs. In natural habitats such an oxygen gradient was found to exist throughout the year, the depth of the anaerobic layer depending on water content, water movement, and sediment composition (see Fenchel \& Jansson 1966, Jansson 1966, 1967a, b, c, Fenchel et al. 1967). Thus, according to the availability of oxygen, most meiofauna taxa migrate vertically within the natural environment. The procedure proposed therefore imitates a process existing in nature.

Specimens able to live in completely anaerobic sediment cannot be expected to be extracted. However, whether metazoans exist continuously in completely anaerobic sediments is controversial (Boaden 1977, 1980, Reise \& Ax 1979, 1980, Powell \& Bright 1981, Powell et al. 1983). Using both methods on the anaerobic sediment layer, no living Metazoa were
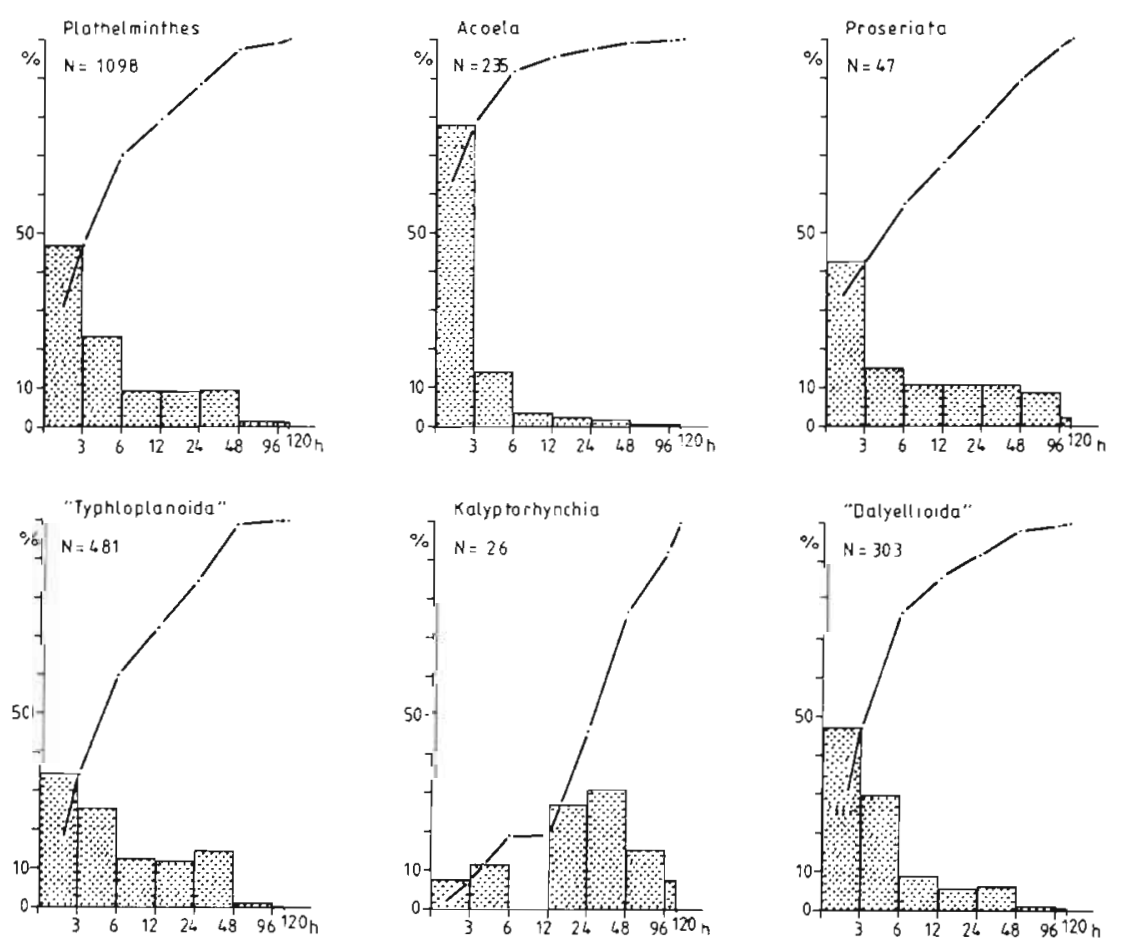

Fig. 2. Plathelminth taxa percentage extraction efficiency within time intervals (log scale), and cumulative percentage extraction efficiency. As there were no differences between salt marsh and Spartina marsh samples, data from both sites were combined. N: number of specimens per taxon; h: hours of extraction 
Table 3. Plathelminthes in Spartina marsh samples (marine); mean number of specimen per taxon in extraction (ex) and control series (co). SD: standard deviation; ns: not significant

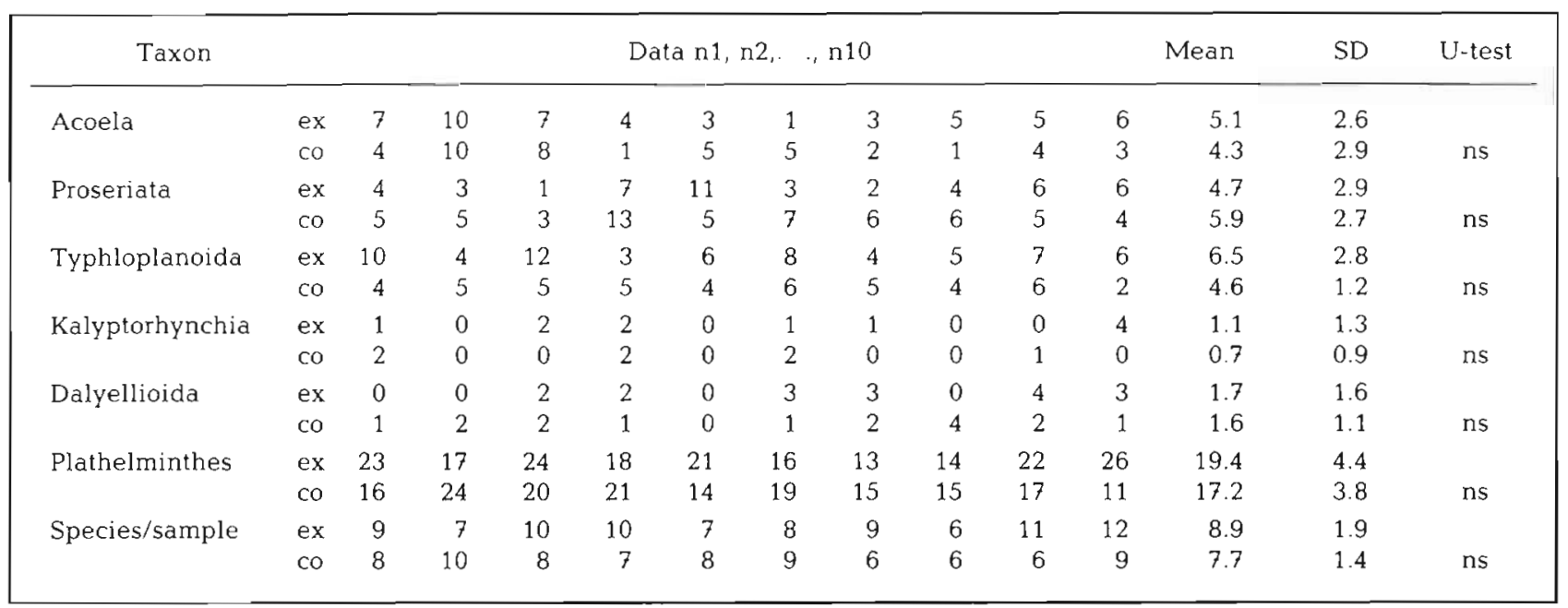

Table 4. Plathelminthes in salt marsh samples (brackish); mean number of specimen per taxon in extraction (ex) and control series (co). SD: standard deviation; ns: not significant; ${ }^{\prime} p \leq 0.05$

\begin{tabular}{|c|c|c|c|c|c|c|c|c|c|c|c|c|c|c|}
\hline Taxon & & & & & & a n 1 & $\ldots$ & 110 & & & & Mean & $\mathrm{SD}$ & U-test \\
\hline \multirow{2}{*}{ Acoela } & ex & 17 & 14 & 33 & 6 & 30 & 4 & 38 & 4 & 20 & 18 & 18.4 & 12.1 & \\
\hline & $\mathrm{CO}$ & 19 & 11 & 18 & 18 & 21 & 10 & 19 & 8 & 3 & 9 & 13.6 & 6.1 & ns \\
\hline \multirow[t]{2}{*}{ Typhloplanoida } & ex & 49 & 49 & 63 & 25 & 74 & 23 & 43 & 32 & 33 & 26 & 41.7 & 17.2 & \\
\hline & $\mathrm{CO}$ & 42 & 32 & 29 & 34 & 40 & 25 & 39 & 15 & 24 & 22 & 30.2 & 8.8 & ns \\
\hline \multirow[t]{2}{*}{ Kalyptorhynchia } & ex & 2 & 2 & 2 & 1 & 3 & 0 & 1 & 0 & 0 & 4 & 1.5 & 1.3 & \\
\hline & $\mathrm{CO}$ & 2 & 0 & 1 & 1 & 6 & 2 & 3 & 2 & 0 & 4 & 2.1 & 1.8 & ns \\
\hline \multirow[t]{2}{*}{ Dalyellioida } & ex & 27 & 32 & 38 & 21 & 84 & 14 & 31 & 10 & 15 & 14 & 28.6 & 21.6 & \\
\hline & $\mathrm{CO}$ & 17 & 13 & 25 & 19 & 13 & 12 & 17 & 8 & 1 & 10 & 13.5 & 6.5 & $\cdot$ \\
\hline \multirow[t]{2}{*}{ Plathelminthes } & ex & 98 & 97 & 136 & 53 & 191 & 41 & 113 & 46 & 67 & 62 & 90.4 & 47.1 & \\
\hline & $\mathrm{CO}$ & 80 & 56 & 73 & 72 & 80 & 49 & 78 & 33 & 28 & 36 & 58.5 & 20.8 & ns \\
\hline \multirow[t]{2}{*}{ Species/sample } & ex & 9 & 9 & 10 & 7 & 9 & 7 & 8 & 10 & 6 & 9 & 8.4 & 1.3 & \\
\hline & $\mathrm{co}$ & 9 & 7 & 7 & 7 & 8 & 9 & 9 & 7 & 3 & 7 & 7.3 & 1.8 & ns \\
\hline
\end{tabular}

found deeper than $5 \mathrm{~mm}$ beyond the oxic/anoxic border, with the exception of tube-dwelling Polychaeta and Crustacea (Nereis diversicolor and Corophium volutator, both living in Spartina marsh only). The walls of their tubes are often oxic due to the pumping activity of the inhabitants, and may contain oxygendependent meiofauna (Anderson \& Meadows 1978, Reise 1981a, b, 1983a, b). For quantitative extraction, these micro-oxidized zones have to be included in the sediment extracted.

Many mud-inhabiting nematode species can live anoxically for a long time (Wieser \& Kanwisher 1961, Teal \& Wieser 1966). Accordingly, nematode extraction needs longer periods. Perhaps quantitative extraction of nematodes would also have been possible in the salt marsh by prolonging the extraction process. The procedure may be used additionally in testing the degree of oxygen demand or tolerance to anaerobic conditions.

In brackish water habitats salt concentration is an important factor. Many plathelminth species of brackish habitats are able to encyst when conditions become worse, and encysted animals cannot be extracted (Armonies 1985). On the other hand, encysted animals may leave their cysts when conditions become favourable. Using salt concentrations other than the range measured at sample collection may alter the species composition. Use of the salt concentration of the sample site, together with an appropriate temperature that completes extraction within $4 \mathrm{~d}$, was found to be sufficient to prevent alteration in plathelminth species composition.

By inducing acceleration of embryogenesis, altered temperature or salinity conditions may also affect the 
number of specimens present within other taxa. Nematoda and Copepoda, for example, are known to be fast-reproducing. For this reason, it seems advisable to keep temperature and salinity within measured ranges.

The new method is based on the principle of 'Klimaverschlechterung' (Riedl 1953). In initial investigations, we found that plathelminths invariably migrate within an oxygen gradient. However, only few species left the sediment and swam freely in the water column above the sediment. The added sand cover, in contrast, is accepted as a substitute substrate. Thus the method simply transfers metazoan microfauna organisms from mud to sand. In further investigations, plathelminths of sandy substrata showed similar upward migrations in an oxygen gradient, and these migrations may be used for concentration of animals near the sediment surface.

The second step of extraction, however, is applicable only for organisms unable to attach to sand grains. Hellwig (1985) found that the shaking-decantation method is able to quantitatively separate metazoan meiofauna from lentic sand flats. However, this method failed in separation of meiofauna from exposed beaches (Noldt \& Wehrenberg 1984).

Thus the new method works best on muddy sediments, for which other treatments like flotation (Barnett 1968), elutrition (Uhlig et al. 1973), or the Uhligseawater-ice-method (Uhlig 1964, 1968) are not applicable. With some practice, separation of the sand cover and separation of animals from the sand will take $10 \mathrm{~min}$ or less. Three Petri dishes containing animals and little sediment will result. If the sand cover is separated 3 times, the total time for extraction amounts to half an hour. Overall, the new method is not very time-consuming, whereas grain-by-grain search of a small sample of $5 \mathrm{~cm}^{3}$ muddy sediment, in contrast, will take several hours.

The method proposed is considered a good means for quantitative extraction of Plathelminthes, Polychaeta, Oligochaeta, Copepoda, and Ostracoda from salt marsh and Spartina marsh sediments. Further investigations have demonstrated that the method also yields quantitative extraction in intertidal mud flats (Hellwig 1985). Its applicability to sediments of other origin and to other taxa than those present at our sample sites remains to be tested.

Acknowledgements. The hospitality of the Biologische Anstalt Helgoland, Litoralstation List is kindly acknowledged. We thank Prof. Peter Ax and Dr. Karsten Reise for continuous help in every way. This study was supported by grant $\operatorname{Re} 425 / 4$ of the Deutsche Forschungsgemeinschaft (DFG) to K. Reise. Uwe Noldt carefully checked the manuscript.

\section{LITERATURE CITED}

Anderson, J. G., Meadows, P. S. (1978). Microenvironments in marine sediments. Proc. R. Soc. Edinb. 76B: 1-16

Armonies, W. (1985). Freilebende Plathelminthen in Salzwiesen der Nordsee: Okologie einer Brackwasserlebensgemeinschaft. Dissertation, Georg-August-Universität Göttingen

Ax, P. (1969). Populationsdynamik, Lebenszyklen und Fortpflanzungsbiologie der Mikrofauna des Meeressandes. Verh. dt. zool. Ges. 1968: 66-113

Barnett, P. R. O. (1968). Distribution and ecology of harpacticoid copepods of an intertidal mudflat. Int. Revue ges. Hydrobiol. 53: 177-209

Boaden, P. J. S. (1977). Thiobiotic facts and fancies (Aspects of the distribution and evolution of anaerobic meiofauna). Mikrofauna Meeresboden 61: 45-63

Boaden, P. J. S. (1980). Meiofaunal thiobios and the Arenicola negation': case not proven. Mar. Biol. 58: 25-29

Fenchel, T., Jansson, B.-O. (1966). On the vertical distribution of the microfauna in the sediments of a brackish water beach. Ophelia 3: 161-177

Fenchel, T., Jansson, B.-O., Thun, W. von (1967). Vertical and horizontal distribution of the metazoan microfauna and of some physical factors in a sandy beach in the northern part of the Øresund. Ophelia 4: 227-243

Gage, J., Geekie, A. D. (1973). Community structure of the benthos in Scottish sea-lochs. II. Spatial pattern. Mar. Biol. 19: 41-53

Hellwig, M. (1985). Ókologie freilebender Plathelminthen im Grenzraum Watt-Salzwiese lenitischer Gezeitenküsten. Dissertation, Georg-August-Universität Göttingen

Hulings, N. C., Gray, J. S. (1971). A manual for the study of meiofauna. Smithson. Contr. Zool. 78: 1-83

Jansson, B.-O. (1966). Microdistribution of factors and fauna in marine sandy beaches. Veröff. Inst. Meeresforsch. Bremerhaven, Sonderbd. 2: 77-86

Jansson, B.-O. (1967a). The availability of oxygen for the interstitial fauna of sandy beaches. J. exp. mar. Biol. Ecol. 1: $123-143$

Jansson, B.-O. (1967b). The importance of tolerance and preference experiments for the interpretation of mesopsammon field distributions. Helgoländer wiss. Meeresunters. 15: $41-58$

Jansson, B.-O. (1967c). The significance of grain size and pore water content for the interstitial fauna of sandy beaches. Oikos 18: 311-322

Martens, P. M. (1984). Comparison of three different extraction methods for Turbellaria. Mar. Ecol. Prog. Ser. 14: $229-234$

Noldt, U., Wehrenberg, C. (1984). Quantitative extraction of living Plathelminthes from marine sands. Mar. Ecol. Prog. Ser. 20: 193-201

Powell, E. N., Bright, T. J. (1981). A thiobios does exist gnathostomulid domination of the canyon community at the East Flower Garden brine seep. Int. Revue ges. Hydrobiol. 66: 675-683

Powell, E. N., Bright, T. J., Woods, A., Gittings, S. (1983) Meiofauna and the thiobios in the East Flower Garden brine seep. Mar. Biol. 73: 269-283

Reise, K., Ax, P. (1979). A meiofaunal 'Thiobios' limited to the anaerobic sulfide system of marine sand does not exist. Mar. Biol. 54: 225-237

Reise, K., Ax, P. (1980). Statement on the thiobios-hypothesis Mar. Biol. 58: 31-32

Reise, K. (1981a). High abundance of small zoobenthos 
around biogenic structures in tidal sediments of the Wadden Sea. Helgoländer Meeresunters. 34: 413-425

Reise, K. (1981b). Gnathostomulida abundant alongside polychaete burrows. Mar. Ecol. Prog. Ser. 6: 329-333

Reise, K. (1983a). Biotic enrichment of intertidal sediments by experimental aggregates of the deposit-feeding bivalve Macoma balthica. Mar. Ecol. Prog. Ser. 12: 229-236

Reise, K. (1983b). Experimental removal of lugworms from marine sand affects small zoobenthos. Mar. Biol. 74 $327-332$

Riedl, R. (1953). Quantitativ ökologische Methoden mariner Turbellarienforschung. Óst. zool. Z. 4: 108-145

Sachs, L. (1984). Angewandte Statistik. Anwendung statistischer Methoden. Springer, Berlin

Teal, J. M., Wieser, W. (1966). The distribution and ecology of nematodes in a Georgia salt marsh. Limnol. Oceanogr. 11 $217-222$

Uhlig, G. (1964). Eine einfache Methode zur Extraction der vagilen, mesopsammalen Mikrofauna. Helgoländer wiss Meeresunters. 11: 178-185

Uhlig, G. (1968). Quantitative methods in the study of interstitial fauna. Trans. microsc. Soc. 87: 226-232

Uhlig, G., Thiel, H., Gray, J. S. (1973). The quantitative separation of meiofauna. A comparison of methods. Helgoländer wiss. Meeresunters. 25: 173-195

Wieser, W., Kanwisher, J. (1961). Ecological and physiological studies on marine nematodes from a small salt marsh near Woods Hole, Massachusetts. Limnol. Oceanogr. 6: $262-270$

This paper was submitted to the editor; it was accepted for printing on November 19, 1985 